\title{
Effect of moderate electric fields in the permeation properties of chitosan coatings
}

\author{
B.W.S. Souza ${ }^{a}$, M.A. Cerqueira ${ }^{a}$, A. Casariego ${ }^{a, b}$, A.M.P. Lima ${ }^{a, c}$, J.A. Teixeira $^{\text {a }}$, A.A. Vicente ${ }^{\mathrm{a}, *}$ \\ a IBB-Institute for Biotechnology and Bioengineering, Center of Biological Engineering, Universidade do Minho, Campus de Gualtar, 4710-057 Braga, Portugal \\ ${ }^{\mathrm{b}}$ Instituto de Farmacia y Alimentos, Universidad de la Habana, La Habana, Cuba \\ ${ }^{\mathrm{c}}$ Depto de Bioquímica e Biologia Molecular, Centro de Ciêcias, Universidade Federal do Ceará Fortaleza, Ceará Brazil
}

\section{A R T I C L E I N F O}

\section{Article history:}

Received 17 July 2008

Accepted 26 March 2009

\section{Keywords}

Edible coatings

Edible films

Moderate electric fields

Chitosan films

\begin{abstract}
A B S T R A C T
Edible films and coatings can provide additional protection for food, while being a fully biodegradable, environmentally friendly packaging system. Preliminary works have shown that the presence of a moderate electric field during the preparation of chitosan coating solutions may influence e.g. their transport properties. If such effect is confirmed, moderate electric fields could be used to tailor edible films and coatings for specific applications. The aim of this work was to determine the effect of field strength on functional properties of chitosan coatings (obtained from lobster from the Cuban coasts). Four different field strengths were tested $\left(50,100,150,200 \mathrm{~V} \mathrm{~cm}^{-1}\right)$ and, for each electric field treatment, the water vapor, oxygen and carbon dioxide permeabilities of the films formed were determined, together with their color, opacity and solubility in water. The surface microstructure of the films was analyzed using atomic force microscopy (AFM).

The results showed that ohmic heating had statistically significant effects on film's physical properties and structure. In general, the most pronounced effect of the field strength was observed for treatments made at $100 \mathrm{~V} \mathrm{~cm}^{-1}$ or higher, a positive correlation being found between the water vapor, oxygen and carbon dioxide permeability coefficients and field strength. The AFM results show that the surface of chitosan films is much more uniform when an electric field is applied, which may be related with a more uniform gel structure leading to the differences observed in terms of transport properties.
\end{abstract}

(c) 2009 Elsevier Ltd. All rights reserved.

\section{Introduction}

Edible coatings can provide an alternative to extend the postharvest life of fresh fruits and other vegetables and can also result in a similar effect as modified atmosphere storage in modifying the internal gas composition (Park, 1999). Indeed, this protective barrier can be formulated to prevent the transfer of moisture, gases, flavor or lipids, and thus to maintain or improve food quality and to increase food product shelf life (Krochta \& De Mulder-Johnson, 1997). Carbohydrates (starches, polysaccharides), proteins, lipids, and combinations of these can be used to make edible films. Chitosan is a chitin derived polysaccharide and is one of the most abundant natural polymers, largely widespread in living organisms such as shellfish, insects, and mushrooms. It is a polysaccharide with linear structure constituted by a copolymer of $\beta-(1-4)$-linked D-glucosamine (GlcN) and N-acetyl-D-glucosamine (GlcNAc) residues (Tharanathan \& Kittur, 2003). It is obtained chiefly by

\footnotetext{
* Corresponding author. Tel.: +351 253 604419; fax: +351 253678986.

E-mail address: avicente@deb.uminho.pt (A.A. Vicente).
}

homogeneous deacetylation of chitin with strong bases, rendering chitosans of different acetyl content or deacetylation degrees. Chitosan is a versatile biopolymer, having a broad range of applications in the food industry (Tharanathan \& Kittur, 2003). The performance of edible coatings depends on their composition and the conditions in which they are used (e.g. relative humidity). A plasticizer is generally required for edible films to overcome film brittleness. Plasticizers could reduce the intermolecular forces and increase the mobility of polymer chains, therefore improving the flexibility and extensibility of the films. Nevertheless, the addition of plasticizers also increases (in general) gas and water vapor permeability of the film, and could possibly decrease the mechanical strength (Gontard, Duchez, Cuq, \& Guilbert, 1994; Mali, Grossmann, García, Martino, \& Zaritzky, 2004).

Ohmic heating is based on the passage of electrical current through a sample that has electrical resistance. The electrical energy is directly converted to heat and instant heating occurs, at a rate which depends on the intensity of the current passing through the material. There are practically no works dealing with the subject of producing edible films under an electric field; Lei, Zhi, Xiujin, Takasuke, and Zaigui (2007) wrote one of the very few, 
where they reported that ohmic heating had many advantages in the production of protein-lipid film, including the improvement of the yield, film formation rate and rehydration capacity of proteinlipid films.

Atomic Force Microscopy (AFM) is one of the techniques that has been used to characterize the surface microstructure e.g. of plasticized soy protein isolate films (Ogale, Cunningham, Dawson, \& Acton, 2000). AFM imaging modes can potentially provide structural information for a sample in its more natural state (without dehydration or coatings) (Lent, Vanasup, \& Tong, 1998). Nanoscale measurements by AFM allow the influence of different factors on the hardness, elasticity and permeability of the film surface to be quantified, which is extremely useful for the design of highperformance edible food packaging systems (Herrmann, Yoshida, Antunes, \& Marcondes, 2004). Measurements of the topography and roughness can be undertaken with extremely high resolution. This technique has been used to characterize the surface morphology of whey protein films (Herrmann et al., 2004; Lent et al., 1998).

The aim of this work was to study the effect of field strength on transport properties of chitosan coatings and film structure, therefore providing insight on the effect of the electric fields on films structure.

\section{Materials and methods}

\subsection{Coating materials}

The materials used to prepare the edible coating solutions were: chitosan (obtained in the Pharmaceutical Laboratories Mario Muñoz, Cuba) with a degree of deacetylation of $90 \%$ approximately, Tween 80 (Acros Organics, Belgium) as surfactant and lactic acid (Merck, Germany).

\subsection{Film formation}

The coating solutions were prepared dissolving the chitosan $(1.5 \% \mathrm{w} / \mathrm{v})$ in a $1 \%(\mathrm{v} / \mathrm{v})$ lactic acid solution with agitation using a magnetic stirrer during $2 \mathrm{~h}$ at room temperature $\left(20{ }^{\circ} \mathrm{C}\right)$; subsequently, Tween 80 was added as a surfactant at a concentration of $0.1 \%(\mathrm{w} / \mathrm{w})$ (Casariego et al., 2008). After homogenizing, the chitosan solution was filtered to remove most of the undissolved impurities ( $<1 \%$ of the chitosan content). At the end of these treatments, a constant amount $(28 \mathrm{~mL})$ of chitosan solution was cast onto an $8 \mathrm{~cm}$ diameter glass plate in order to maintain the film thickness. The films were dried in an oven at $35{ }^{\circ} \mathrm{C}$ during $8 \mathrm{~h}$. Dried films were peeled from the plate and cut in circles with $8 \mathrm{~cm}$ of diameter, approximately, for property testing.

\subsection{Device description}

A set of experiments was conducted to determine the effect of the application of a moderate electric field to chitosan solutions. The chitosan solution samples were treated in an ohmic heater using four different field strengths (from 50 to $200 \mathrm{~V} \mathrm{~cm}^{-1}$ ) with a $2 \mathrm{~cm}$ gap between the electrodes, in all cases leading to an increase of temperature up to $60{ }^{\circ} \mathrm{C}$. The heater and data acquisition system used are represented in Fig. 1 and consisted of a cylindrical glass tube of $30 \mathrm{~cm}$ total length and $2.3 \mathrm{~cm}$ inside diameter; two Titanium electrodes with Teflon pressure caps were placed at each end of the tube (for details of the apparatus please refer to Castro, Teixeira, Salengke, Sastry, \& Vicente, 2004). Samples were heated using an alternating current source of $50 \mathrm{~Hz}$, with different field strengths. Temperatures were

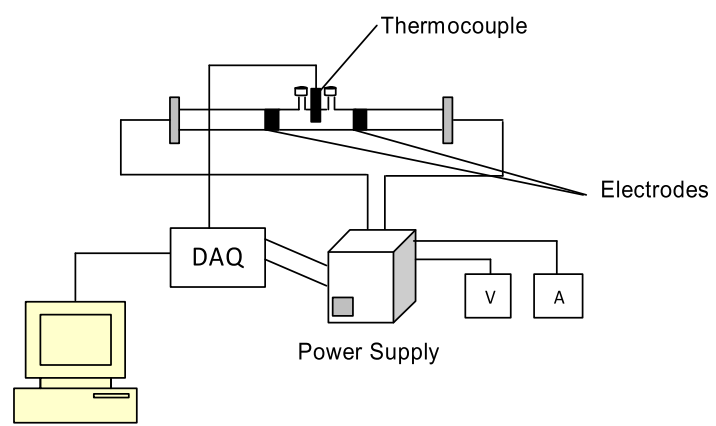

Fig. 1. Ohmic heater and data acquisition system.

monitored using a type- $\mathrm{K}$ thermocouple, placed at the geometrical centre of the chamber though the available opening. A datalogger was employed to record continuously and simultaneously, current intensity, voltage and temperature. In order to measure voltage across and current through the samples voltage and current transducers were used, respectively.

In order to collect data for the conventional heating, $30 \mathrm{~mL}$ Falcon tubes containing the chitosan solution samples were placed in a temperature controlled water bath. The thermal history of the samples, until temperature stabilization, was monitored by the introduction of a thermocouple connected to the data acquisition system previously described; this treatment was used as control in order to discard the temperature effects and to evaluate only the effects of electric field.

\subsection{Characterization of chitosan films}

\subsubsection{Conditioning}

All chitosan films used for permeability tests were conditioned in desiccators, at $20^{\circ} \mathrm{C}$ and $25 \% \mathrm{RH}$.

\subsubsection{Thickness}

Film thickness was measured with a hand-held digital micrometer (Mitutoyo, Japan) having a sensitivity of $0.001 \mathrm{~mm}$. Ten thickness measurements were taken on each testing sample in different randomly chosen points and the mean values were used in permeability calculations.

\subsubsection{Optical properties}

The color of films was determined with a Minolta colorimeter (CR 300; Minolta, Japan). A white color plate $(Y=93.5, x=0.3114$, $y=0.3190)$ was used as standard for calibration. The CIELab scale was used to measure lightness $(L)$ and chromaticity parameters $a^{*}$ (red - green) and $b^{*}$ (yellow - blue). Measurements were performed placing the film sample over the standard. Samples were analyzed in triplicate, recording four measurements for each sample.

The opacity of a material is an indication of how much light passes through it. How higher the opacity, lower the amount of light that can pass through the material. Generally, opacity is calculated from reflectance measurements. The opacity of the samples was determined, according to Hunter lab method, as the relationship between the opacity of each sample on a black standard $\left(Y_{b}\right)$ and the opacity of each sample on the white standard $\left(Y_{\mathrm{w}}\right)$ :

Opacity $=\frac{Y_{b}}{Y_{w}} \times 100 \%$

where $Y$ is the CIE tristimulus value. 


\subsubsection{Gases permeability}

Oxygen permeability $\left(\mathrm{O}_{2} \mathrm{P}\right)$ and carbon dioxide permeability $\left(\mathrm{CO}_{2} \mathrm{P}\right)$ were determined based on the ASTM (2002) method. A chitosan film was sealed between two chambers, having each one two channels to the exterior. In the lower chamber $\mathrm{O}_{2}$ or $\mathrm{CO}_{2}$ were supplied at a controlled flow rate to keep the pressure constant in that compartment. The upper chamber was purged by a stream of nitrogen, also at a controlled flow. This nitrogen acted as a carrier for the $\mathrm{O}_{2}$ or $\mathrm{CO}_{2}$ coming from the lower chamber though the film. The flows of the two chambers were connected to manometers to ensure the equality of pressures between both compartments, kept at $1 \mathrm{~atm}$. As the $\mathrm{O}_{2}$ or $\mathrm{CO}_{2}$ were carried continuously by the nitrogen flow, it was considered that $\mathrm{O}_{2}$ or $\mathrm{CO}_{2}$ partial pressure in the upper compartments is null, therefore $\Delta P$ can be considered to be $1 \mathrm{~atm}$ $\mathrm{O}_{2} \mathrm{P}$ was determined from the measurements of $\mathrm{O}_{2}$ concentration in the nitrogen flow leaving the chamber with an $\mathrm{O}_{2}$ sensor installed on-line. $\mathrm{CO}_{2} \mathrm{P}$ was determined from the measurements of $\mathrm{CO}_{2}$ concentration in a gas chromatograph (Chrompack 9001, Middelburg, Netherlands) with a column Porapak Q 80/100 mesh$2 \mathrm{~m} \times 1 / 8^{\prime \prime} \times 2 \mathrm{~mm}$ SS (Temperatures: Oven $=35^{\circ} \mathrm{C}$, detector and injector $=110^{\circ} \mathrm{C}$; flow of the carrier gas $=23 \mathrm{~mL} \mathrm{~min}^{-1}$ ). In all cases the variation coefficient obtained between the three replicates made for each experiment was below $5 \%$.

\subsubsection{Water vapor permeability measurement}

The water vapor permeability (WVP) of the films was determined gravimetrically based on the ASTM E96-92 method (Guillard, Broyart, Bonazzi, Guilbert, \& Gontard, 2003; Mc Hugh, AvenaBustillos, \& Krochta, 1993). The test film was sealed on the top of a permeation cell containing distilled water $\left(100 \% \mathrm{RH} ; 2.337 \times 10^{3} \mathrm{~Pa}\right.$ vapor pressure at $20^{\circ} \mathrm{C}$ ), placed in a desiccator which was maintained at $20{ }^{\circ} \mathrm{C}$ and $0 \% \mathrm{RH}$ ( 0 Pa water vapor pressure) with silica gel. The water transferred through the film and adsorbed by the desiccant was determined from weight loss of the permeation cell. The cups were weighed at intervals of $2 \mathrm{~h}$ during $10 \mathrm{~h}$. Steady-state and uniform water pressure conditions were assumed by keeping the air circulation constant outside the test cup by means of a miniature fan placed inside the desiccators (Mc Hugh et al., 1993). The slope of the curve representing the weight loss versus time was obtained by linear regression. The measured (WVP) of the films was determined as follows:

$\mathrm{WVP}=(\mathrm{WVTR} \cdot L) / \Delta P$

where WVTR is the measured water vapor transmission rate $\left(\mathrm{g} \cdot \mathrm{m}^{-2} \mathrm{~s}^{-1}\right)$ through the film (calculated from the slope of the curve divided by the area of the film), $L$ is the mean film thickness ( $m$ ), and $\Delta P$ is the partial water vapor pressure difference ( $\mathrm{Pa}$ ) across the two sides of the film. For each type of film, WVP measurements were replicated three times and the variation coefficient obtained was at all times below $5 \%$.

\subsubsection{Film solubility}

The film solubility in water was determined according to the method reported by Gontard et al. (1994). It was defined by the content of dry matter solubilized after $24 \mathrm{~h}$ immersion in water. The initial dry matter content of each film was determined by drying it to constant weight in an oven at $105{ }^{\circ} \mathrm{C}$. Two disks of film ( $2 \mathrm{~cm}$ diameter) were cut, weighed, and immersed in $50 \mathrm{~mL}$ of water. After $24 \mathrm{~h}$ of immersion at $20{ }^{\circ} \mathrm{C}$ with occasional agitation, the pieces of film were taken out and dried to constant weight in an oven at $105^{\circ} \mathrm{C}$, to determine the weight of dry matter which was not solubilized in water. The variation coefficient obtained between the three replicates made for each experiment was below $5 \%$.

\subsubsection{Atomic force microscopy}

The surface morphology of the films was analyzed by AFM with a Nanoscope III, Multimode (Digital Instruments) with a $10 \mu \mathrm{m} \times 10 \mu \mathrm{m}$ scan size and a $3.5 \mu \mathrm{m}$ vertical range. Measurements were taken from several areas of the film surface $(10 \mu \mathrm{m} \cdot 10 \mu \mathrm{m})$ using the tapping mode. The resulting data set for each sample was transformed into a 3D image. The average sample roughness (ASME B46.1, 1995) $(R a)$ was estimated with the aid of the built-in software of the equipment.

\subsubsection{Statistical analysis}

Analysis of Variance (ANOVA) and linear regression were the main statistical tools used for data analysis. The Tukey test ( $\alpha=0.05$ ) was also used to determine the significance of differences between specific means (SigmaStat 3.1, 2004, Excel, 2003, USA).

\section{Results and discussion}

\subsection{Oxygen permeability $\left(\mathrm{O}_{2} \mathrm{P}\right)$ and carbon dioxide permeability $\left(\mathrm{CO}_{2} \mathrm{P}\right)$}

Permeability is a steady-state property that describes the extent to which a permeating substance dissolves and then the rate at which it diffuses through a film, with a driving force related to the difference in concentration of that substance between the two sides of the film (Gennadios, 2002).

Gas permeabilities of edible films and coatings depend on several factors such as the integrity of the film, the ratio between crystalline and amorphous zones, the hydrophilic-hydrophobic ratio and the polymeric chain mobility; the interaction between the film-forming polymer and the presence of a plasticizer or other additives are also important factors in film permeability (Garcia, Martino, \& Zaritzky, 2000).

The measurement of the permeability of edible films to oxygen and carbon dioxide provides important information for the development of edible films. Oxygen is the key factor that might cause oxidation, inducing several unwanted food changes such as odor, color and flavor, as well as nutrients deterioration. Therefore, films providing a proper oxygen barrier can help improving food quality and extending food shelf life (Sothornvit \& Pitak, 2007). Carbon dioxide is formed in some foods due to deterioration and respiration reactions. The produced $\mathrm{CO}_{2}$ has to be removed from the package to avoid food deterioration and/or package destruction (Vermeiren, Heirlings, Devlieghere, \& Debevere, 2003). Such films can maintain food quality and improve stability and shelf life by retarding unwanted mass transfer in food products (Miller \& Krochta, 1997), including to retard transport of gases $\left(\mathrm{O}_{2}, \mathrm{CO}_{2}\right)$ for fruits and vegetables, migration of moisture for dried and intermediate moisture foods, and migration of solutes for frozen foods.

Table 1 shows $\mathrm{O}_{2} \mathrm{P}$ and $\mathrm{CO}_{2} \mathrm{P}$ as measured for chitosan films formed from solutions subjected to electric fields of different intensities. The samples with treatments made at $100 \mathrm{~V} \mathrm{~cm}^{-1}$ or higher have lower values $(p<0.05)$ of $\mathrm{O}_{2} \mathrm{P}$ and $\mathrm{CO}_{2} \mathrm{P}$.

The AFM observation of a regular surface of the chitosan films treated at $100 \mathrm{~V} \mathrm{~cm}^{-1}$ or above (confirmed by the $R a$ values) as opposed to a rougher surface of the untreated films indicates that the films structure might have been altered due to the application of the electric field during the preparation of the film-forming solution (see Table 1 and also Fig. 3). Wan, Creber, Preppley, and Bui (2003) observed that the crystallinity of the chitosan membranes increased gradually with increasing degree of deacetylation ranging from 70 to $90 \%$. This can be attributed to the fact that chains of chitosan with higher degree of deacetylation are more compact thus facilitating hydrogen-bonding formation and consequently 
Table 1

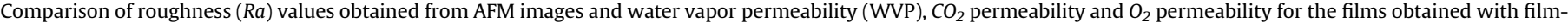
forming solutions subjected to different field strengths.

\begin{tabular}{|c|c|c|c|c|}
\hline Electric field strength & $R a(\mathrm{~nm})$ & $W V P\left(g \cdot(\text { m.day.atm })^{-1}\right)$ & $\mathrm{CO}_{2}$ Permeability $10^{14}\left(\mathrm{~g} \cdot \mathrm{m} \cdot\left(\text { Pa.s. } \mathrm{m}^{2}\right)^{-1}\right)$ & $\mathrm{O}_{2}$ Permeability $10^{16}\left(\mathrm{~g} \cdot \mathrm{m} \cdot\left(\text { Pa.s. } \mathrm{m}^{2}\right)^{-1}\right)$ \\
\hline $0 \mathrm{~V} \mathrm{~cm}^{-1}$ & 10.22 & $0.3228 \pm 0.027^{\mathrm{a}}$ & $6.98 \pm 0.030^{\mathrm{a}}$ & $10.60 \pm 0.420^{\mathrm{a}}$ \\
\hline $50 \mathrm{~V} \mathrm{~cm}^{-1}$ & 20.13 & $0.3219 \pm 0.022^{\mathrm{a}}$ & $6.97 \pm 0.029^{a}$ & $10.60 \pm 0.450^{a}$ \\
\hline $100 \mathrm{~V} \mathrm{~cm}^{-1}$ & 7.75 & $0.2740 \pm 0.027^{\mathrm{b}}$ & $6.74 \pm 0.037^{b}$ & $9.54 \pm 0.400^{b}$ \\
\hline $150 \mathrm{~V} \mathrm{~cm}^{-1}$ & 4.71 & $0.2728 \pm 0.030^{\mathrm{b}}$ & $6.72 \pm 0.041^{\mathrm{b}}$ & $9.42 \pm 0.540^{b}$ \\
\hline $200 \mathrm{~V} \mathrm{~cm}^{-1}$ & 4.01 & $0.2667 \pm 0.025^{\mathrm{b}}$ & $6.72 \pm 0.040^{\mathrm{b}}$ & $9.62 \pm 0.600^{b}$ \\
\hline
\end{tabular}

*Different letters in the same column correspond to statistically different samples $(p<0.05)$.

favoring crystallinity formation in the film. Furthermore, chitosan with a higher degree of deacetylation contains more glucosamine groups, which also facilitate the hydrogen-bonding formation; on the contrary, chitosan with a lower degree of deacetylation has more acetyl groups, which hinder the chitosan chain packing due to their rigidity and steric effect (Bangyekan, Aht-Ong, \& Srikulkit, 2006). Lei et al. (2007) studied the effects of different heating methods on the production of protein-lipid film and concluded that the major advantage of ohmic heating is that the heat is dispersed uniformly throughout the whole liquid compared to water bath heating, and finally concluded that the film formation rate was higher when ohmic heating was applied. During the heating process, heat was uniformly applied to the whole volume of the film, accelerating the collisions between molecules. This process can provide an improvement in the crystallinity of the chitosan film, thus increasing the material's resistance to gas permeation. Balau, Lisa, Popa, Tura, and Melnig (2004) studied the X-ray difractogram of chitosan films, an almost amorphous structure; the films treated with an electric field of $E=20 \mathrm{kV} \mathrm{cm}^{-1}$, developed a crystalline structure, while the films to which no electric field was applied displayed a significantly lower proportion of crystalline material, showing that the electric field plays an important role in the crystallization process.

\subsection{Water vapor permeability}

Water vapor permeability (WVP) is an important parameter commonly considered in food packaging. WVP comprises sorption, diffusion and adsorption and is largely governed by the interactions between the polymer and the water molecules (Nivedita, Sangaj, \& Malshe, 2004). Water permeation through a film usually occurs through the hydrophilic part of the film, thus the relation of the hydrophilic/hydrophobic portions is important to determine WVP. Polymers with high hydrogen-bonding produce films that are susceptible to moisture while polymers with hydrophobic groups make excellent barrier to moisture. Generally, WVP is also

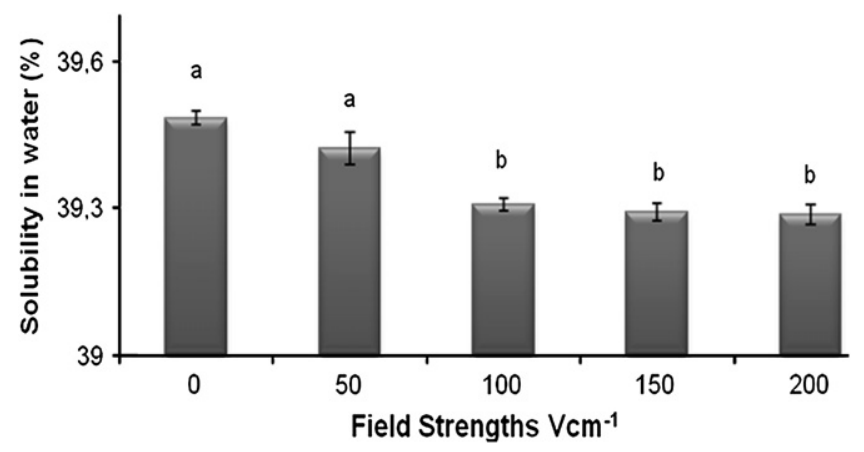

Fig. 2. Solubility in water of chitosan films treated different electrical field strengths. Different letters in the same column correspond to statistically different samples $(p<0.05)$. depended on the pore size of the film (Paramawati, Yoshino, \& Isobe, 2003). In fact, WVP tends to increase with polarity, degree of unsaturation and degree of ramification of the lipids used (if any), in addition to the effect of the water molecule sorption by the polar part of the film material (Gontard et al., 1994).

Butler, Vergano, Testin, Bunn, and Wiles (1996) reported that chitosan films are highly impermeable to oxygen, however they have relatively poor water vapor barrier characteristics, which result from their hydrophilicity.

The water vapor permeability should be as low as possible since an edible film or coating should retard moisture transfer between the food and the environment, or between two components of a heterogeneous food product (Gontard, Guilbert, \& Cuq, 1992).

The results obtained in this work show that WVP of chitosan films decrease (up to $17.3 \%$ ) with the increase of the field strengths for values of $100 \mathrm{~V} \mathrm{~cm}^{-1}$ or higher. These films showed lower WVP values than those of other hydrocolloids films reported in literature (Bravin, Peressini, \& Sensidoni, 2006; Mathew \& Abraham, 2008; Olivas \& Barbosa-Cánovas, 2008; Vargas, Albors, Chiralt, \& González-Martínez, 2009; Ziani, Oses, Coma, \& Maté, 2008).

There is a positive correlation between WVP and film surface roughness $(R a)$. The increase of the field strength seems to be correlated with the permeability and $R a$ (see Table 1 ). Herrmann et al. (2004) observed that an increase of protein concentration lead to an increase of the viscosity of the film-forming solution, which resulted in the incorporation of air bubbles; this formed nonhomogeneous and non-compact film networks, increasing the roughness and, as a consequence, the value of $W V P$.

Anker, Stading, and Hermansson (2000) concluded that the reason for the increased $W V P$ is probably the larger pores formed at high polymer concentration, compared to the smaller pores formed at low polymer concentration. The work of Miller and Krochta (1997) also points at the fact that the permeability is highly affected by how closely packed the polymer chains are, thus establishing a direct relationship between the crystallinity of the structure and permeability.

Table 1 summarizes the results for $\mathrm{Ra}, \mathrm{WVP}, \mathrm{O}_{2} \mathrm{P}$ and $\mathrm{CO}_{2} \mathrm{P}$.

\subsection{Solubility in water and optical properties}

\subsubsection{Solubility in water}

Solubility in water is defined as the maximum percentage (by weight) of a substance that will dissolve in a unit volume of water at certain (usually room) temperature. It is an important property, which governs potential applications of these materials to food preservation. Films with low water solubility are necessary for the protection of foodstuffs with high or intermediate water activity (Sébastien, Stéphane, Copinet, \& Coma, 2006). On the other hand, edible films with high water solubility may be required, for example, to contain premeasured portions which will be dissolved in water or in hot food (Guilbert \& Biquet, 1989).

In the present work the solubility of the chitosan films was evaluated, and it is shown that the solubility of chitosan films 

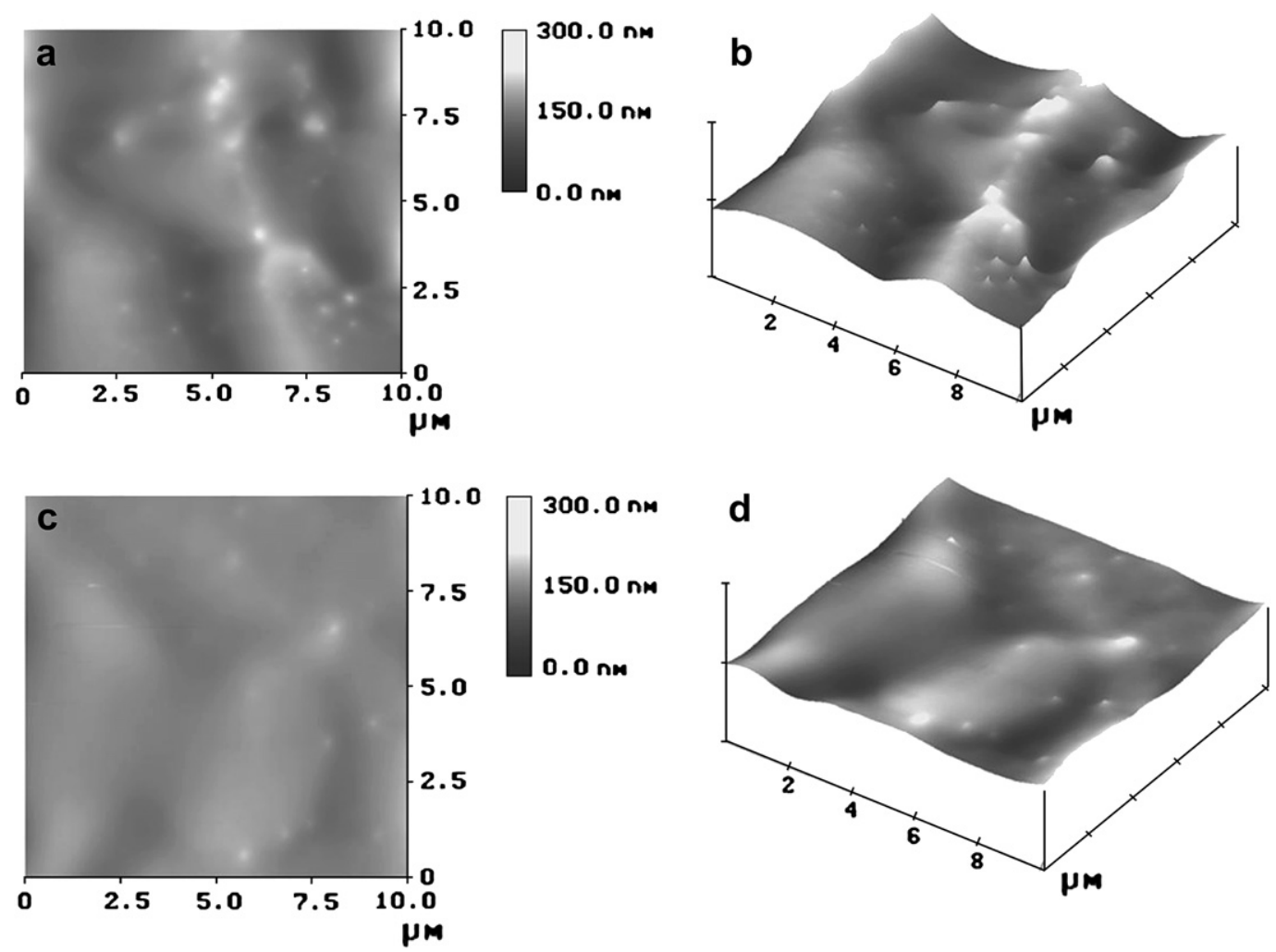

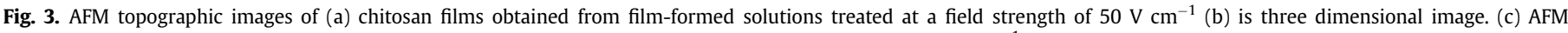
topographic images of chitosan films obtained from film-formed solution treated at a field strength of $100 \mathrm{~V} \mathrm{~cm}-1(\mathrm{~d})$ is three dimensional image.

decrease with the increase of the field strengths for values of $100 \mathrm{~V} \mathrm{~cm}^{-1}$ or higher (Fig. 2). Balau et al. (2004) showed that the electric field plays an important role in the crystallization process, which may also interfere in the water solubility of the films. In fact, similarly to what has been reported for gas permeability, the solubility of chitosan films has been associated to the crystallinity of the sample; a high crystallinity contributes to a higher insolubility (Du \& Hsieh, 2007), and the poor solubility of chitosan has been attributed to its partially crystalline structure (Nishimura, Kohgo, Kurita, \& Kuzuhara, 1991).

\subsubsection{Optical properties}

The results of the measurements of color are shown in Table 2. The films should be visually attractive, and should not change their color throughout the time of storage, in order not to harm the acceptance of the product on which they are applied.

The results show that the lightness of chitosan films is somewhat lower when an electric field is applied, but still high. For comparison, results for the lightness of albumen (from egg) range between 95.67 and 96.20 (Gennadios, Weller, Hanna, \& Fronnig, 1996); such films were reported to be clearer and more transparent

Table 2

Optical properties of chitosan films.

\begin{tabular}{lllll}
\hline Electric field strenght & $L^{*}$ (lightness) & $a^{*}$ & $b^{*}$ & Opacity (\%) \\
\hline $0 \mathrm{~V} \mathrm{~cm}^{-1}$ & $93.80 \pm 0.38^{\mathrm{a}}$ & $4.04 \pm 0.11^{\mathrm{a}}$ & $11.01 \pm 0.46^{\mathrm{a}}$ & $4.98 \pm 1.11^{\mathrm{a}}$ \\
$50 \mathrm{~V} \mathrm{~cm}^{-1}$ & $94.01 \pm 0.72^{\mathrm{a}}$ & $4.15 \pm 0.17^{\mathrm{a}}$ & $11.64 \pm 0.56^{\mathrm{a}}$ & $5.05 \pm 0.97^{\mathrm{a}}$ \\
$100 \mathrm{~V} \mathrm{~cm}^{-1}$ & $93.68 \pm 0.56^{\mathrm{a}}$ & $4.29 \pm 0.27^{\mathrm{a}}$ & $20.73 \pm 1.57^{\mathrm{b}}$ & $5.07 \pm 0.28^{\mathrm{a}}$ \\
$150 \mathrm{~V} \mathrm{~cm}^{-1}$ & $93.73 \pm 0.91^{\mathrm{a}}$ & $4.50 \pm 0.40^{\mathrm{a}}$ & $21.26 \pm 1.64^{\mathrm{b}}$ & $5.06 \pm 0.61^{\mathrm{a}}$ \\
$200 \mathrm{~V} \mathrm{~cm}^{-1}$ & $93.84 \pm 0.98^{\mathrm{a}}$ & $4.00 \pm 0.47^{\mathrm{a}}$ & $20.34 \pm 1.46^{\mathrm{b}}$ & $4.89 \pm 0.47^{\mathrm{a}}$ \\
\hline
\end{tabular}

*Different letters in the same column correspond to statistically different samples $(p<0.05)$. than films based on wheat, soy protein and corn zein, studied by the same authors. Further, the values of lightness for chitosan films are higher than those reported for wheat protein films, which presented values of $L$ between 83.3 and 89.7 (Rayas, Hernandez, \& Perry, 1997). The high values of the component $b^{*}$ indicate the predominance of the yellow color in the chitosan films; this coincides with the data reported by Butler et al. (1996). Our results also indicate that an increase in the field strength leads to a significant increase of the values of $b^{*}$ (see Table 2). In general, polysaccharide films are free from the color problems associated with protein (which can suffer Maillard reactions) and lipid (which can suffer oxidation) films (Trezza \& Krochta, 2000).

The evaluation of the opacity of a material demonstrates its greater or lesser transparency. For the development of materials meant to be used as films or coatings for food, increased transparency tends to be better (Yang \& Paulson, 2000) once the goal is to retain the original features of the product, such as color.

The values of opacity (Table 2 ) for the films under consideration did not differ significantly ( $p<0.05$ ); all films were transparent, meaning that there was no apparent effect due to the application of an electrical field.

\section{Conclusions}

The results obtained showed that the application of a moderate electric field to the film-forming solutions has statistically significant effects on the film's physical properties and structure. In general, the most pronounced effect of the field strength was observed for treatments made at $100 \mathrm{~V} \mathrm{~cm}^{-1}$ or higher. The solubility in water and the water vapor, oxygen and carbon dioxide permeability coefficients showed a positive correlation with the application of an electric field. The AFM results show that the surface of chitosan films is much more uniform when an electric 
field is applied as shown by the roughness results obtained, which may be related to the differences observed in terms of transport properties.

In practice, the changes in the film properties induced by the application of the electrical field may translate in an improved shelf life of the products due to reduced water loss (calculated on the basis of the lower WVP values achieved) and reduced $\mathrm{O}_{2}$ and $\mathrm{CO}_{2}$ exchanges (due to the lower values of $\mathrm{O}_{2} \mathrm{P}$ and $\mathrm{CO}_{2} \mathrm{P}$ ), which will mean a slower metabolism e.g. in fruits and vegetables (Casariego et al., 2008). Future work should be directed towards the confirmation of these effects in real food systems.

\section{Acknowledgments}

The author B.W.S. Souza is the recipient of a fellowship from the Coordenação de Aperfeiçoamento de Pessoal de Nível Superior (CAPES, Brazil), the authors A. Casariego and A.M.P Lima received a fellowship from the $\alpha$ LFA VALNATURA Project of the Europe Aid Cooperation Office, and author M.A. Cerqueira is recipient of a fellowship from the Fundação para a Ciência e Tecnologia (FCT, Portugal).

\section{References}

Anker, M., Stading, M., \& Hermansson, A.-M. (2000). Relation between the microstructure and the mechanical and barrier properties of whey protein films. Journal Agricultural Food Chemistry, 48, 3806-3816.

ASME B46.1. (1995). Surface texture: Surface roughness, waviness and lay. New York: ASME. An American National Standard.

ASTM D 3985-02. (2002). Standard test method for oxygen gas transmission rate through plastic film and sheeting using a coulometric sensor. In ASTM Book of standards 15.09 .

Balau, L., Lisa, G., Popa, M. I., Tura, V., \& Melnig, V. (2004). Physico-chemical properties of Chitosan films. Central Europe Journal of Chemistry, 2(4), 638-647.

Bangyekan, C., Aht-Ong, D., \& Srikulkit, K. (2006). Preparation and properties evaluation of chitosan-coated cassava starch films. Carbohydrate Polymers, 63, 61-71.

Bravin, B., Peressini, D., \& Sensidoni, A. (2006). Development and application of polysaccharide-lipid edible coating to extend shelf-life of dry bakery products. Journal of Food Engineering, 76, 280-290.

Butler, B. L., Vergano, P. J., Testin, R. F., Bunn, J. M., \& Wiles, J. L. (1996). Mechanical and barrier properties of edible chitosan film as affected by composition and storage. Journal of Food Science, 61(5), 953-961.

Casariego, A., Souza, B. W. S., Vicente, A. A., Teixeira, J. A., Cruz, L., \& Díaz, R. (2008) Chitosan coating surface properties as affected by plasticizer, surfactant and polymer concentrations in relation to the surface properties of tomato and carrot. Food Hydrocolloids, 22, 1452-1459.

Castro, I., Teixeira, J. A., Salengke, S., Sastry, S. K., \& Vicente, A. A. (2004). Ohmic heating of strawberry products: electrical conductivity measurements and ascorbic acid degradation kinetics. Innovative Food Science and Emerging Technologies, 5, 27-36.

Du, J., \& Hsieh, Y.-L. (2007). PEGylation of chitosan for improved solubility and fiber formation via electrospinning. Cellulose, 14, 543-552.

Garcia, M. A., Martino, M. N., \& Zaritzky, N. E. (2000). Lipid addition to improve barrierproperties of edible sartch-based films and coatings. Journal of food science, 65(6), 941-947.

Gennadios, A., Weller, M. A., Hanna, M. A., \& Fronnig, G. W. (1996). Mechanical and barrier properties of egg albumen film. Journal of Food Science, 61(3), 585-589.

Gennadios, A. (2002). Protein-based films \& coatings. CRC Press. 672

Gontard, N., Duchez, C., Cuq, J. L., \& Guilbert, S. (1994). Edible composite films of wheat gluten and lipids: water vapor permeability and other physical properties. International Journal of Food Science and Technology, 2, 39-50.

Gontard, N., Guilbert, S., \& Cuq, J. L. (1992). Edible wheat gluten films: influence of the main process variables on film properties using response surface methodology. Journal of Food Science, 57(1), 190-199.
Guilbert, S., \& Biquet, B. (1989). Les films et enrobage comestibles. In L'EMBALLAGE des denrées alimentaires de grande consommation. Technique et Documentation, Lavoisier Apri. 320.

Guillard, V., Broyart, B., Bonazzi, C., Guilbert, S., \& Gontard, N. (2003). Preventing moisture transfer in a composite food using edible films: experimental and mathematical study. Journal of Food Science, 68(7), 2267-2277.

Herrmann, P. S. P., Yoshida, C. M. P., Antunes, A. J., \& Marcondes, J. A. (2004). Surface evaluation of whey protein films by atomic force microscopy and water vapour permeability analysis. Packaging Technology and Science, 17, 267-273.

Krochta, J. M., \& De Mulder-Johnson, C. (1997). Edible and biodegradable polymer films: challenges and opportunities. Food Technology, 51(2), 61-77.

Lei, L., Zhi, H., Zhang Xiujin, Z., Takasuke, I., \& Zaigui, L. (2007). Effects of different heating methods on the production of protein-lipid film. Journal of Food Engineering, 82, 292-297.

Lent, L. E., Vanasup, L. S., \& Tong, P. S. (1998). Whey protein edible films determined by atomic force microscope. Journal Food Science, 63, 824-827.

Mc Hugh, T. H., Avena-Bustillos, R. J., \& Krochta, J. M. (1993). Hydrophilic edible film: modified procedure for water vapor permeability and explanation of thickness effects. Journal Food Science, 58, 899-903.

Mali, S., Grossmann, M. V. E., García, M. A., Martino, M. N., \& Zaritzky, N. E. (2004). Barrier, mechanical and optical properties of yam starch films. Carbohydrate Polymers, 56, 129-135.

Mathew, S., \& Abraham, T. E. (2008). Characterisation of ferulic acid incorporated starch-chitosan blend films. Food Hydrocolloids, 22, 826-835.

Miller, K. S., \& Krochta, J. M. (1997). Oxygen and aroma barrier properties of edible films. Trends in Food Science E Technology, 8, 228-237.

Nishimura, S., Kohgo, O., Kurita, K., \& Kuzuhara, H. (1991). Chemospecific manipulations off a rigid polysaccharide: syntheses off novel chitosan derivatives with excellent solubility in common organic solvents by regioselective chemical modifications. Marcomolecules, 24, 4745-4748.

Nivedita, S., Sangaj, N. S., \& Malshe, V. C. (2004). Permeability of polymers in protective organic coatings. Progress in Organic Coatings, 50, 28-39.

Ogale, A. A., Cunningham, P. Dawson, P. L. \& Acton, J. C. (2000). Viscoelastic thermal, and microstructural characterization of soy protein isolate films. Journal of Food Science, 65(4), 672-679.

Olivas, G. I., \& Barbosa-Cánovas, G. V. (2008). Alginate-calcium films: water vapor permeability and mechanical properties as affected by plasticizer and relative humidity. LWT-Food Science and Technology, 41, 359-366.

Paramawati, R., Yoshino, T., \& Isobe, S. (2003). Pengaruh degradable plasticizer tunggal terhadap karakteristik film dari zein. [Effect of degradable platicizer on tensile and barrier properties of single plasticized-zein film]. Jurnal Enjiniring Pertanian, 1(1), 49-57.

Park, H. J. (1999). Development of advanced edible coatings for fruits. Trends Food Science Techonology, 10, 254-260.

Rayas, L. M., Hernandez, R. J., \& Perry, K. W. N. G. (1997). Development and characterization of biodegradable/edible wheat protein film. Journal of Food Science, 61(1), 160-162.

Sébastien, F., Stéphane, G., Copinet, A., \& Coma, V. (2006). Novel biodegradable films made from chitosan and poly(lactic acid) with antifungal properties against mycotoxinogen strains. Carbohydrate Polymers, 65, 185-193.

Sothornvit, R., \& Pitak, N. (2007). Oxygen permeability and mechanical properties of banana films. Food Research International, 40, 365-370.

Tharanathan, R. N., \& Kittur, F. S. (2003). Chitin - The undisputed biomolecule of great potential. Critical Review in Food Science and Nutrition, 43(1), 61-87.

Trezza, T. A., \& Krochta, J. M. (2000). Color stability of edible coatings during prolonged storage. Journal of Food Science, 65(7), 1166-1169.

Vargas, M., Albors, A., Chiralt, A., \& González-Martínez, C. (2009). Characterization of chitosan-oleic acid composite films. Food Hydrocolloids, 23, 536547.

Vermeiren, L., Heirlings, L., Devlieghere, F., \& Debevere, J. (2003). Oxygen, ethylene and other scavengers. In Raija Ahvenainen. (Ed.), Novel food packaging techniques. Woodhead Publishing Limited/CRC Press LLC.

Wan, Y., Creber, K. A. M., Preppley, B., \& Bui, V. T. (2003). Ionic conductivity of chitosan membranes. Polymer, 44, 1057-1065.

Yang, L., \& Paulson, A. T. (2000)Effects of lipids on mechanical and moisture barrier properties of edible gellan film, 33. Amesterdam: Food Research International. 571-578.

Ziani, K. Oses, J. Coma, V. \& Maté, J. I. (2008). Effect of the presence of glycerol and Tween 20 on the chemical and physical properties of films based on chitosan with different degree of deacetylation LWT. Food Science and Technology, 41, 2159-2165. 